\section{Ichthyofaunal diversity in Great Nicobar Biosphere Reserve, Bay of Bengal}

\section{R. Rajaram ${ }^{1} \&$ T. Nedumaran ${ }^{2}$}

${ }^{1}$ Department of Marine Science, Bharathidasan University, Tiruchirapalli, Tamil Nadu 620024, India

${ }^{2}$ Centre of Advanced Study in Marine Biology, Annamalai University,

Parangipettai 608502, Tamil Nadu, India

Email: ${ }^{1}$ drrajaram69@ rediffmail.com

The Andaman and Nicobar Islands are well known for their rich variety of fish. Rao et al. (2000) reported 539 fish species from the freshwater and marine habitats of the islands. A wide variety of fish species occur in Great Nicobar waters owing to the diversity of marine habitats, including mangroves, creeks, lagoons, estuaries, muddy shores and coral reefs; Dhandapani \& Mishra (1998) recorded 88 species belonging to 55 genera, 33 families and seven orders, with Perciformes being the dominant order. Local fisheries provide important food and commercial resources (Kumaran 1973; Marichamy 1974; Sivaprakasam 1976a,b; Menon 1977; Sudarsan 1978; Talwar et al. 1982; Dorairaj \& Soundararajan 1985, 1987; Mehta \& Devi 1990; Talwar 1990; Rajan et al. 1992; Rao et al. 1992; Dhandapani \& Mishra 1993; Rajan et al. 1993; Rao \& Devi 1996; Devi \& Rao 1997; Dhandapani \& Mishra 1998; Devaraj et al. 1999; Rao et al. 2000; Ghosh 2001; Rajaram et al. 2007). The marine fishery resources of the Andaman and Nicobar Islands are estimated to be around 0.244 million tonnes, representing over $6 \%$ of the estimated marine fishery potential of India. Annual marine fish landing in these waters is about 27000 tonnes, accounting for $11 \%$ of the Indian total (Ghosh 2001 ).

\section{Materials and Methods}

The Andaman and Nicobar islands, located in the Bay of

Date of publication 26 March 2009

ISSN $0974-7907$ (online) | 0974-7893 (print)

Editor: M. Arunachalam

\section{Manuscript details:}

Ms \# 01985

Received 23 April 2008

Final revised received 14 October 2008

Finally accepted 09 February 2009

Citation: Rajaram, R. \& T. Nedumaran (2009). Ichthyofaunal diversity in Great Nicobar Biosphere Reserve, Bay of Bengal. Journal of Threatened Taxa 1(3): 166-169.

Copyright: (C R. Rajaram \& T. Nedumaran 2009. Creative Commons Attribution 3.0 Unported License. JoTT allows unrestricted use of this article in any medium for non-profit purposes, reproduction and distribution by providing adequate credit to the authors and the source of publication.

Acknowledgements: The authors are thankful to the Ministry of Environment and Forests, Government of India for providing financial support; to Shri D.R.K. Sastri, Officer-In-Charge, Andaman and Nicobar Regional Station, Zoological Survey of India, Port Blair for permitting us to make use of the library and laboratory facilities; to Shri. N. Yesu Rathnam, Divisional Forest Officer and Shri B. Chatterjee, Wildlife Warden of Campbell Bay, Great Nicobar Islands for the encouragement and facilities and to the Indian Coast Guard for the logistic support.

OPEN AGCESS | FREE DOWNLOAD
Bengal, include 524 islands of which 30 are inhabited. The 24-island Nicobar island group includes Great Nicobar, which is covered by thick forest $(70 \%)$ and has a coastal system of reefs, mangroves, estuaries and wetlands (Fig 1). Collections were conducted in three-month periods over three years from August 2000 to July 2003 in primary fishing locations around Great Nicobar (Campbell Bay, Lashman Beach, Jawahal Nullah, Gandhi Nagar, Vijaya Nagar, Laful Bay, Kondul, Pillobhabi, Galathea Bay and River, Kopen Heat) using a variety of fishing gear including shore seines, gillnets, cast nets, hook and line, and scoop nets. Scoop net collections were also made in all the low tide collection stations on both the east and west coasts. Specimens were also procured from Zero Point fish market at Campbell Bay, and landing centers including Gandhi Nagar and Vijaya Nagar. The specimens were fixed in 10\% formalin.

\section{Results and Discussion}

In the second year of collection, 75 species of new record belonging to 55 genera, 75 species, 40 families and 13 orders were reported. Among these, Perciformes topped the list with 24 families, 34 genera and 50 species followed by Anguilliformes (2 families with 5 genera and 7 species), Scorpaeniformes (2 families with 3 genera and 5 species), Tetraodontiformes and Cyprinodontiformes ( 2 families with 2 genera and 2 species each), Laminiformes (single family with single genus and species). The orders Clupeiformes, Pleuronectiformes, Syngnathiformes, Siluriformes, Aulopiformes, Elopiformes and Rajiformes were represented by a single family with single genus and species each. In Perciformes, the families Carangidae with six species, Haemulidae and Mullidae with three species each and Lutjanidae with two species are the major families showing new distribution records.

During the entire study, 258 species belonging to 141 genera, 84 families and 19 orders were recorded. Among these, Perciformes topped the list with 47 families, 84 genera and 169 species followed by Clupeiformes (4 families with 9 genera and 16 species), Tetraodontiformes ( 5 families with 8 genera and 16 species), Anguilliformes (5 families with 9 genera and 15 species), Scorpaeniformes (3 families with 5 genera and 8 species), Beryciformes ( 1 family with 3 genera and 5 species), Laminiformes ( 1 family with 2 genera and 4 species), Cyprinodontiformes and Pleuronectiformes (3 families with 3 genera and 4 species), Rajiformes ( 2 family with 2 genera and 3 species), Myctophiformes and Syngathiformes (1 family with 2 genera and 3 species), Aulopiformes (a single family with 2 genera and 2 species), Siluriformes ( 2 families with 2 genera and 2 species) and Notacanthiformes, Elopiformes and Ophidiformes were each represented by a single species.

In Anguilliformes, 10 species of muraenid eel including the two species Rhinomuraena quaesita and Moringua bicolor and Neoniphon aurolineatus, belonging to the Holocentridae family under the order Beryciformes, are new distribution records to the Bay of Bengal. In Perciformes, Carangidae with 17 species, Serranidae with 12 species, Lutjanidae, Clupeidae and Pomocentridae with nine species each, Haemulidae with seven species, Apogonidae with four species, Chaetodontidae with five species, Pomacanthidae with two species, Scaridae with three species are the major families which include the commercially 


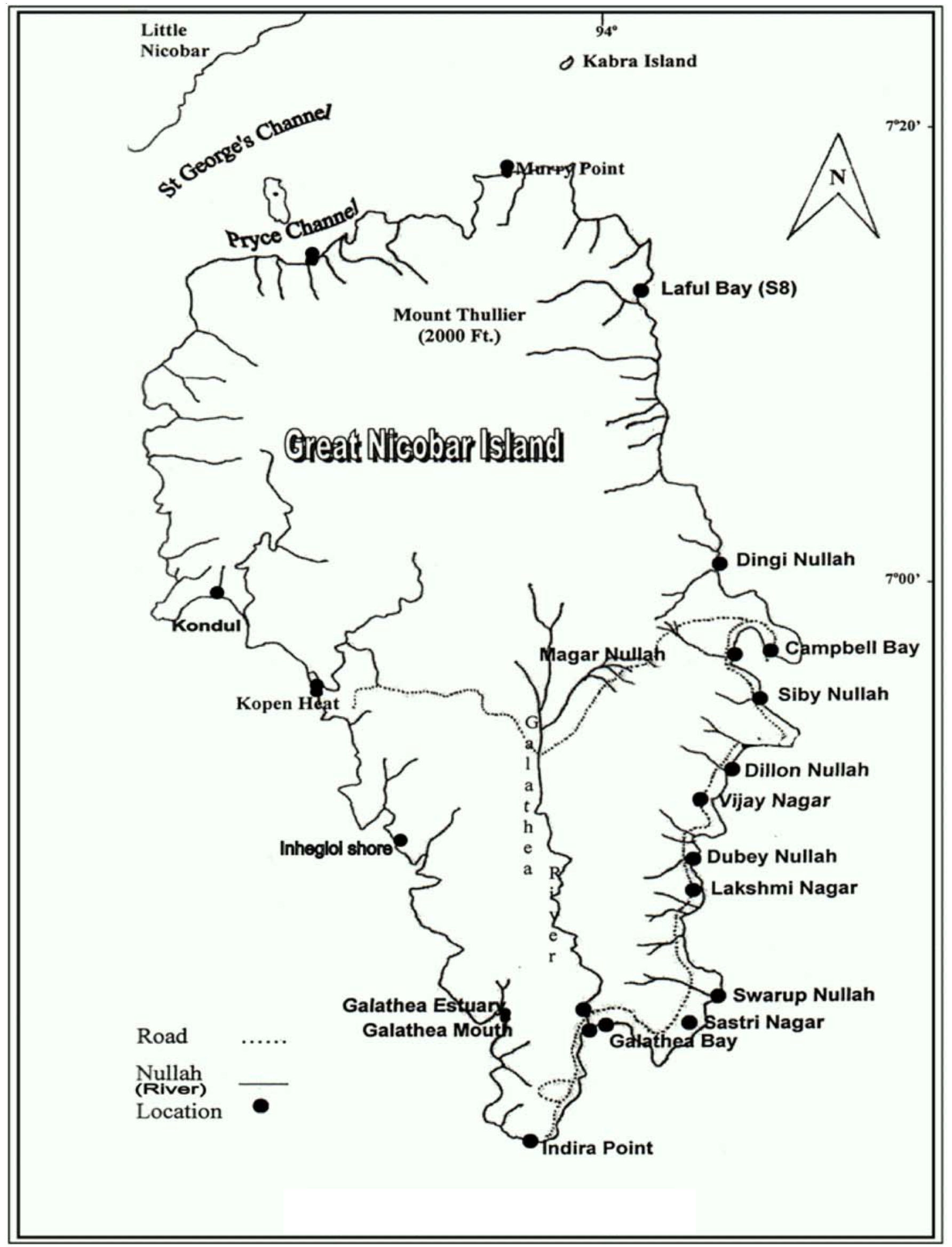

Figure 1. Map of Great Nicobar Island with fish catch sites in the study. 
Table 1. Lists of new distributional records in the Great Nicobar Biosphere Reserve

Class : Chondrichthyes

Order: Laminiformes

Family : Carcharhinidae

1. Carcharhinus melanopterus (Quoy \& Gaimard

1824)

Family : Anguillidae

2. Carcharhinus hemiodon (Valenciennes, in Muller \& Henle 1839)

Order : Rajiformes

Family : Dasyatidae

3. Dasyatis kuhlii (Muller \& Henle 1841)

4. Anguilla bicolor bicolor (Mc Clelland 1844)

Order : Anguilliformes

Family : Muraenidae

5. Echidna nebulosa (Ahl 1789)

6. Gymnothorax flavimarginatus (Ruppell 1830)

7. Gymnothorax fimbriatus (Bennett 1831)

8. Gymnothorax pictus (Ahl 1789)

9. Gymnothorax richardsoni (Bleeker 1852)

10. Uropterygius tigrinus (Lesson 1829)

11. Uropterygius marmoratus (Lacepede 1803)

12. Siderea picta (Ahl 1789)

13. Rhinomuraena quaesita (Garman 1888)*

Family : Moringuidae

14. Moringua bicolor (Kaup 1856)*

Family : Ophichthidae

15. Myrichthys colubrinus (Boddaert 1781)

Order : Clupeiformes

Family : Clupeidae

16. Amblygaster siram (Walvaum 1742 )

17. Sardinella sp. (Valenciennes 1847)

18. Hilsa sp. (Regan 1917)

Family : Engraulidae

19. Thryssa baelama (Forsskal 1775)

Order : Aulopiformes

Family : Synodontidae

20. Saurida undosquamis (Richardson 1848)

Order : Siluriformes

Family : Ariidae

21. Plotosus lineatus (Thunberg 1787)

Order: Ophidiiformes

Family : Carapidae

22. Carapus homei (Richardson 1844)

Order : Myctophiformes

Family : Myctophidae

23. Benthosema pterotum (Alcock)

24. Diaphus sp. (Klunzinger)

Order : Cyprinodontiformes

Family : Hemiramphidae

25. Hemiramphus far (Forsskal 1775)

Family : Exocoetidae

26. Cypselurus poecilopterus (Valenciennes 1846)

Order : Beryciformes

Family : Holocentridae

27. Neoniphon aurolineatus (Lienard 1839)*

Order : Syngnathiforms

Family : Syngnathidae

28. Corythoichthys haematopterus (Bleeker 1851)

29. Myripristis murdjan (Forsskal 1775)

30. Sargocentron sp. (Fowler 1904)

31. Sargocentron rubrum (Forsskal 1775)

32. Hippocampus sp. (Rafilesque 1810)

33. Hippocampus kuda (Bleeker 1852)

Order : Perciformes

Family : Ambassidae

34. Ambassis commersoni (Cuvier \& Valenciennes)

Family : Serranidae

35. Epinephelus coioides (Hamilton 1822)

36. Epinephelus fasciatus (Forsskal 1775)

Family: Priacanthidae

37. Priacanthus hamrur (Forsskal 1775)

38. Apogon cookii (Macleay 1881)

39. Apogon hyalosoma (Bleeker 1852)
40. Apogon novemfasciatus (Cuvier)

Family : Terapontidae

41. Terapon theraps (Cuvier 1829)

Family : Rachycentridae

42. Rachycentron canadus (Linnaeus 1766)

Family : Carangidae

43. Selar tol(Cuvier 1832)

44. Selar crumenophthalmus (Bloch 1739)

45. Selaroides leptolepis (Cuvier 1833)

46. Caranx sp. (Lacepede 1801)

47. Caranx ignobilis (Forsskal 1775)

48. Caranx sexfasciatus (Quoy \& Gaimard 1824)

49. Caranx melampygus (Cuvier 1833)

50. Carangoides oblongus (Cuvier 1833)

51. Carangoides armatus (Ruppell 1830)

52. Gnathanodon speciosus (Forsskal 1775)

Family : Leiognathidae

53. Leiognathus jonesi (James)

Family : Lutjanidae

54. Lutjanus sp. (Bloch 1790)

55. Lutjanus johni (Bloch 1792)

56. Lutjanus fulviflamma (Forsskal 1775)

57. Lutjanus rivulatus (Cuvier 1828)

58. Aprion virescens (Valenciennes 1830)

Family : Gerreidae

59. Gerres oblongus (Cuvier 1830)

60. Gerres oyena (Forsskal 1775)

Family : Haemulidae

61. Pomadasys furcatus (Bloch \& Schneider 1801)

62. Pomadasys argyreus (Valenciennes 1833)

63. Pomadasys hasta (Bloch 1790)

64. Diagramma pictum (Thunberg 1792)

Family : Lethrinidae

65. Lethrinus harak (Forsskal 1775)

66. Lethrinus lentjan (Lacepede 1802)

Family : Labridae

67. Halichoeres scapularis (Bennett 1831)

68. Labroides sp. (Bleeker 1851)

69. Xyrichthys pentadactylus (Linnnaeus 1758)

70. Xyrichthys sp. (Cuvier 1815)

71. Thalassoma lunare (Linnaeus 1758)

Family : Nemipteridae

72. Scolopsis cancellatus (Valenciennes 1820)

Family : Sciaenidae

73. Pteroscirtes breviceps (Valenciennes 1836)

Family : Mullidae

74. Parupeneus bifasciatus (Lacepede 1801)

75. Upeneus taeniopterus (Cuvier 1829)

76. Upeneus vittatus (Forsskal 1775)

Family : Caesionidae

77. Caesio caerulaurea (Lacepede 1801)

78. Caesio varilineata (Carpenter 1987)

Family : Kyphosidae

79. Kyphosus cinerascens (Forsskal 1775)

80. Kyphosus vaigiensis (Quoy \& Gaimard 1825)

Family : Menidae

81. Mene maculata (Bloch \& Sch. 1801)

Family : Ephippidae

82. Platax orbicularis (Forsskal 1775)

83. Platax pinnatus (Linnaeus 1758)

84. Platax tiera (Forsskal 1775)

Family : Plesiopidae

85. Plesiops sp.

86. Plesiops caeruleolineatus (Ruppell, 1835)

87. Plesiops corallicola (Bleeker 1853)

Family : Chaetodontidae

88. Chaetodon sp. (Linnaeus 1758)

89. Chaetodon auriga (Forsskal 1775)

90. Chaetodon falcula (Bloch 1793)

91. Chaetodon guttatissimus (Bennett 1832)

Family : Mugilidae

92. Liza sp. (Jordon \& Swainson 1894)

93. Liza vaigiensis (Quoy \& Gaimard 1825)

94. Valamugil seheli (Forsskal 1775)

95. Valamugil buchanani (Bleeker 1854)

96. Mugil cephalus (Linnaeus 1758)

97. Oedalechilus labiosus (Valenciennes)

Family : Sphyraenidae

98. Sphyraena jello (Cuvier 1829)
99. Sphyraena putamiae (Jordan \& Seale 1905)

Family : Pomacentridae

100. Amphiprion sp. (Block \& Schneider 1801)

101. Chrysiptera sp. (Swainson 1839)

102. Chrysiptera biocellata (Quoy \& Gaimard 1825)

103. Chrysiptera glauca (Cuvier 1830)

104. Chrysiptera caeruleolineatus (Allen 1973)

105. Chrysiptera unimaculata (Cuvier 1830)

106. Abudefduf septemfasciatus (Cuvier 1830)

107. Abudefduf vaigiensis (Quoy \& Gaimard 1825)

108. Dascyllus aruamus (Linnaeus, 1758)

Family : Polynemidae

109. Polynemus melanochir (Linnaeus 1758)

110. Polynemus plebeius(Broussonet 1782)

Family : Scaridae

111. Scarus sp. (Forsskal 1775)

112. Scarus sordidus (Forsskal)

Family : Blennidae

113. Entomacrodus sp. (Gill 1859)

114. Salarias fasciatus (Bloch 1786)

Family : Eleotridae

115. Ophieleotris aporos (Bleeker 1854)

116. Butis butis (Ham - Buch. 1822)

Family : Gobiidae

117. Acentrogobius bontii (Bleeker 1849)

118. Gobioidon sp. (Bleeker 1856)

119. Oxyurichthys tentacularis (Valenciennes

1837)

Family : Acanthuridae

120. Acanthurus sp. (Forsskal 1775)

121. Acanthurus lineatus (Linnaeus 1758)

122. Acanthurus thompsoni (Fowler)

123. Acanthurus xanthopterus (Valenciennes 1835)

124. Naso vlamingii (Valenciennes 1835)

125. Ctenochaetus striatus (Quoy \& Gaimard

1825)

Family : Siganidae

126. Siganus javus (Linnaeus 1766)

127. Siganus lineatus (Valenciennes 1835)

Family : Channidae

128. Channa sp. (Scopoli 1777)

Family : Toxotidae

129. Toxotes jaculator (Pallas 1766)

Order: Pleuronectiformes

Family : Bothidae

130. Bothus sp. (Rafinesque 1810)

131. Bothus pantherinus (Ruppell 1830)

Family : Paralichthyidae

132. Pseudorhombus tricellatus (Schneider 1801)

Order : Scorpaeniformes

Family : Scorpaenidae

133. Tetraroge sp. (Gunther 1860)

134. Scorpaenodes sp. (Bleeker 1857)

135. Scorpaenodes guamensis (Cuvier \& Gaimard 1824)

136. Pterois antennata (Bloch 1787)

137. Pterois volitans (Linnaeus 1758)

138. Pterois radiata (Cuvier 1829)

Family : Platycephalidae

139. Platycephalus indicus (Linnaeus 1758)

Family : Synanceiidae

140. Synanceia verrucosa (Bloch \& Sch. 1801)

Order : Tetraodontiformes

Family : Balistidae

141. Balistapus undulates (Mungo Park 1797)

142. Balistapus viridescens (Bloch \& Sch. 1801)

143. Rhinecanthus aculeatus (Linnaeus 1758)

Family : Ostracidae

144. Lactoria cornuta (Linnaeus 1758)

Family : Tetraodontidae

145. Arothron stellatus (Bloch \& Sch.)

Family : Triacanthidae

146. Pseudotriacanthus strigilifer (Cantor 1849)

147. Diodon liturosus (Shaw 1804)

* New distribution records to Bay of Bengal

(Image 1) 

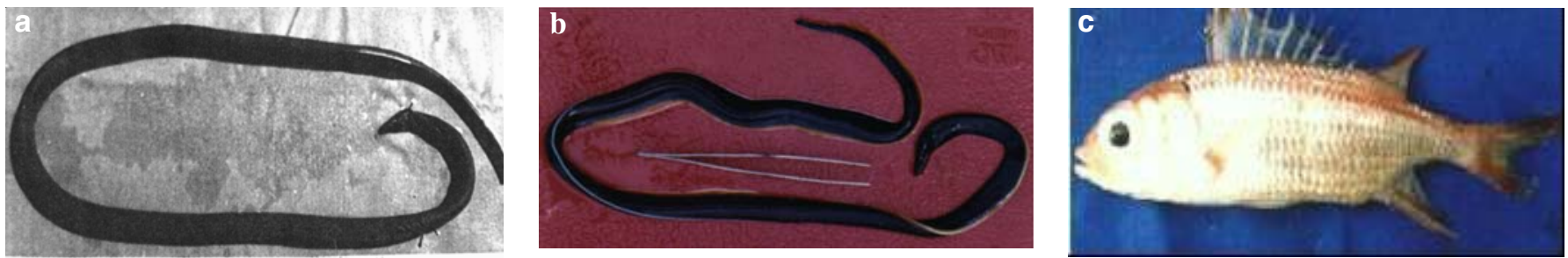

Image 1. New distribution records from the Bay of Bengal

a - Moringua bicolor (Kaup, 1856); b - Rhinomuraena quaesita (Garman, 1888); c - Neoniphon aurolineatus (Linenard, 1839)

and ornamentally important species.

From the entire survey, 147 species of new distribution records in the study area belonging to 15 orders, 97 genera and 59 families are reported. Among these, Perciformes topped the list with 33 families, 57 genera and 99 species followed by Anguilliformes ( 3 families with 7 genera and 11 species), Tetraodontiformes (4 families with 6 genera and 7 species), Scorpaeniformes (3 families with 5 genera and 8 species), Clupeiformes (2 families with 4 genera and 4 species). Rhinomuraena quaesita (Muraenidae), Moringua bicolor (Moringuedae) belonging to Anguilliformes and Neoniphon aurolineatus (Holocentridae) of Beryciformes, upon their collection from Great Nicobar Islands form new distributional records to the Bay of Bengal.

\section{References}

Devaraj, M., H.M. Kasim, C. Muthiah \& N.G.K. Pillai (1999). Assessment of the exploited seer fish stocks in the Indian waters. Journal of Marine Biological Association of India 41(1\&2): 62-84.

Dhandapani, P. \& S.S Mishra (1993). New records of marine fishes from Great Nicobar. Journal of Andaman Science Association 9(1\&2): 58-62.

Dhandapani, P. \& S.S. Mishra (1998). Fish resources of the Great Nicobar Island and their potentiality for sustainable utilization. Island Ecosystem and Sustainable Development, Port Blair, India. Journal of Andaman Science Association vol(no): 139-146.

Dorairaj, K. \& R. Soundararajan (1985). Exploited marine fishery resources of Andaman and Nicobar Islands. Journal of Andaman Science Association $1(1): 49-58$.

Dorairaj, K. \& R. Soundararajan (1987). Coastal environment and fishery resources of the Bay Islands. Proceedings of the Symposium on Management of Coastal Ecosystem and Oceanic Resources of the Andamans, pp.40-49.

Ghosh, S.K. (2001). Andaman and Nicobar Islands - Untapped fishery resources. Bay of Bengal News 18-21.

Jones, S. \& K. Banerjee (1973). A review of the living resources of the Central Indian Ocean. Proceedings of Symposium on living resources of the seas around India. Special publication, CMFRI, Cochin, $1-17 \mathrm{pp}$.

Devi, K. \& D.V. Rao (1997). New records of reef fishes from Andaman waters. Journal of Andaman Science Association 13(1\&2): 104-106.
Kumaran, M. (1973). The fishery potentials of the Andaman and Nicobar Islands. Proceedings of Symposium on living resources of the seas around India. Special publication, CMFRI, Cochin, 387-389pp.

Marichamy, R. (1974). The fisheries resources of the Andaman sea. Sea Food Export Journal 6(10): 27-31.

Mehta, H.S. \& K. Devi (1990). Four new records of gobioid fishes from Andaman and Nicobar Islands. Journal of Andaman Science Association 6(1): 66-68.

Menon, P.M.G. (1977). The economic development of Andaman and Nicobar Islands by increased fisheries development activities. Sea Food Export Journal 9(9): 9-15

Rajan, P.T., D.V. Rao \& K. Devi (1992). New records of butterfly fishes from Andaman and Nicobar Islands. Journal of Andaman Science Association 8(2): $172-174$.

Rajan, P.T., D.V. Rao, K. Devi \& S. Dey (1993). New records of rare fishes from Andaman Islands. Journal of Andaman Science Association 9(1\&2): 103-106

Rajaram, R., M. Srinivasan, S. Ajmal Khan, L. Kannan, D.V. Rao \& K. Devi (2007). New records of two eel fishes from Great Nicobar Island, Bay of Bengal. Journal of the Bombay Natural History Society 104(2): 228-229.

Rao, D.V. \& K. Devi (1996). Notes on rabbit fishes (Family: Siganidae) of Andaman and Nicobar Islands. Journal of Andaman Science Association 12(1\&2): 84-88.

Rao, D.V., K. Devi \& P.T. Rajan (2000). An account of ichthyofauna of Andaman and Nicobar Islands, Bay of Bengal. Records of the Zoological Survey of India Occ. Paper No. 178: 1-434

Rao, D.V., P.T. Rajan \& K. Devi (1992). New records of groupers (Family: Serranidae) and cardinal fishes (Family: Apogonidae) from Andaman and Nicobar Islands. Journal of Andaman Science Association 8(1): 47-52.

Sivaprakasam, T.E. (1976a). The off-shore fisheries, pp.173-175. In: Editors. The Andaman and Nicobar information. Andaman and Nicobar Administration.

Sivaprakasam, T.E. (1976b). The off-shore fisheries, pp.82-89. In: Editors. The Andaman and Nicobar information. Andaman and Nicobar Administration.

Sudarsan, D. (1978). Fish trawl catches of shoal Bay, Port Blair (Andaman) in relation to hydrology and plankton. Matsya 3: 83-85.

Talwar, P.K. (1990). Fishes of Andaman and Nicobar Islands: a synoptic analysis. Journal of Andaman Science Association 6(2): 71-102.

Talwar, P.K., T.K. Chatterjee \& M.K.D. Roy (1982). Oxyurichthys dasi, a new gobioid (Pisces: Gobiidae) from the Andaman Islands. Records of the Zoological Survey of India 79(3/4): 483-487. 